\title{
Sociologies Perspectives on Unregistered Marriages in Muslim Socities
}

\author{
Zed Bachmid ${ }^{1 *}$, Malkan Malkan ${ }^{2}$, Ali Imron ${ }^{3}$
}

\footnotetext{
${ }^{1}$ Islamic Family Law Department, Postgraduate, Institut Agama Islam Negeri Palu 2 Islamic Family Law Department, Postgraduate, Institut Agama Islam Negeri Palu

${ }^{3}$ Islamic Family Law Department, Postgraduate, Institut Agama Islam Negeri Palu
}

ABSTRACT

The study focuses on the practical concept of the unregistered marriage at the Marawola Sub-district. It seeks to understand factors that cause the practices and their sociological impacts. The study aims to recognize the practical concept of the unregistered marriage, factors affecting the practices, and their sociological impacts. The study is a descriptive research by nature. It employs different data collection techniques while adopting qualitative approach in its data analysis. The setting of the study is at the Marawola Sub-district. The findings of the study show that there were a lot of people in the community under the authority of the Marawola Sub-district practiced unregistered marriages. They made mention that the reasons for their practices which were derived from their interviews were legal because they believed that the unregistered marriages have fulfilled terms and conditions for lawful marriages. They argued that a marriage registration is only for the legalization of the marriage. The reasons for the unregistered marriage practices covered many factors. First, it is due to the ignorance of the community in regards to procedures for a marriage registration at the Marawola Sub-district. Other reasons are related to administrative requirements for a marriage registration and marriages by accident due to pregnancies. In addition, unlawful actions of irresponsible individuals in the community who helped perpetrators to find a shortcut for the Unregistered Marriages could also cause the insurgence of the practices. These all brought sociological impacts in their society especially for wives and children where there is no legal protection for them. Hence, there was no recognition from formal law which then resulted in longterm social impacts and negative turmoil in the community.
ARTICLE

INFORMATION

\section{Keywords: \\ Unregistered \\ marriage, sociologies \\ perspectives, Islamic \\ law, social impact}




\section{Introduction}

Marriage is an agreement between a man and a woman, in this case, marriage is a sacred agreement with the aim of forming an eternal and happy family. It has been stated in Qur' an verse Ar-Ruum [30]: 21) which mean "And it is among His signs that He has created for you wives from among yourselves, so that you may find tranquility in them, and He has created love and kindness between you. Surely in this there are signs for a people who reflect." 1

According to Law No. 1 of 1974 Article 1, marriage is an inner and outer bond between a man and a woman as husband and wife to form a happy and eternal family (household) based on the One God. ${ }^{2}$

As well contained in the noble values of Pancasila, which are based on the 1945 Constitution. So, formulate these ideals through government programs and laws and regulations to set them as guidelines and measures for the creation of the nation's ideals through State ministry institutions according to needs. ${ }^{3}$ Delegation of authority and required areas of work. The government's main task towards its people through the state

\footnotetext{
${ }^{1}$ Yayasan Penyelenggara Penerjemah Al-

Qur'an Depertemen Agama RI, Al-Qur'an Tiga

Bahasa, (Jakarta: Al-Huda, 2009), 641

${ }^{2}$ Republik Indonesia, Undang-undang Nomor

1 Tahun 1974 tetang Perkawinan, bab I, pasal 1.

3 Muslih, I., Nurdin, N., \& Marzuki, M. (2020). Effectiveness of Marriage Services Through Information System Management (SIMKAH) at Palu City Religious Court INTERNATIONAL JOURNAL OF CONTEMPORARY ISLAMIC LAW AND SOCIETY, 2(1), 20-36.
}

civil apparatus is to provide services to meet the needs desired by the community for the welfare of the people.

Development and public services in the field of religion are also one of the important pillars in government activities $^{4}$ which are manifested by their existence through the Ministry of Religion, from the provincial, district to sub-district levels. All have the same role in providing services to the community, but it is the district level that plays the most role because it is directly in contact with the community. In this case, the Islamic religious court is the spearhead of the Ministry of Religion in providing services to the community, especially marriage and reconciliation issues, because this is one of the main functions and duties of the Islamic religious court.

To maximize the results and objectives of the government in providing services to the community, the government issued a regulation on marriage registration through Law number 1 of 1974 so that the government's goals for the welfare of the community were achieved. ${ }^{5}$ However, many people do not carry out the

${ }^{4}$ Musyahidah, S., Ermawati, E., \& Nurdin, N. (2021). The Effect of Riba Avoidance and Product Knowledge on the Decision to Become a Customer of Islamic Banks. International Journal of Multidisciplinary Research and Analysis, 4(8), 10901101.

${ }^{5}$ Nasir, M., Abidin, Z., \& Thahir, L. S. (2021). Pre-Marital Counseling Effectiveness In Building Happy Muslim Families INTERNATIONAL JOURNAL OF CONTEMPORARY ISLAMIC LAW AND SOCIETY, 3(1), 56-68. 
marriage registration rules, causing turmoil in society, both social turmoil and legal turmoil.

Based on the census data conducted by the Non-Governmental Organization (NGO) for the Empowerment of Women Headed Families, 25 percent of the people in Indonesia still have marriages that are not registered in the state or unregistered marriage in 2012. This census was conducted in 111 villages of 17 provinces. There are several provinces where marriages are not registered to above 50 percent in the state. In NTT 78 percent, Banten 65 percent, and NTB 54 percent. ${ }^{6}$

Based on the data from NonGovernmental Organizations (NGOs) above, it can be concluded that since 2012 there are still many practices of unregistered marriage in a number of regions in several provinces in Indonesia. This is a national sample that the practice of unregistered marriage is still a social problem in the midst of society so that the role of government institutions through the Ministry of Religion is needed, namely the District Religious Affairs Office, which is the spearhead of the Ministry of Religion in providing marriage services as well as prevention and socialization solutions about the impact of unregistered marriage to reduce and provide understanding to the

\footnotetext{
${ }^{6}$ Henny Rachma Sari, "25 Persen Masyarakat Indonesia Melakukan Nikah Siri”, Merdeka Online. 26 Desember 2012. https://www.merdeka.com/peristiwa/25-persenmasyarakat-indonesia-melakukan-nikah-siri.html,$\quad(10$ Januari 2019)
}

public about the negative impacts of unregistered marriage pratices.

Government agencies through the Ministry of Religion also continue to try to prevent it by providing solutions to the community so as not to practice unregistered marriage through various ways, including the Government issuing Regulation Number 48 of 2014 concerning Marriage and Referral Fees which was issued on 27 June 2014. This Government Regulation is an amendment to Government Regulation Number 47 of 2004 concerning "Tariffs on Non-Tax State Revenues applicable to the Ministry of Religion."

The changes stipulated in PP No. 48 of 2014 include the existence of multiple tariffs imposed on people who are getting married.

In PP Number 48 of 2014, it is stated in article 6: (1) Every citizen who carries out marriage or reconciliation at the Islamic religious court or outside the Islamic religious court is not charged a marriage registration fee or reconciliation. (2) In the event that marriage or reconciliation is carried out outside the Sub-District Islamic religious court, transportation and professional services fees are charged as receipts from the Islamic religious court; (3) Citizens who are economically incapable and disaster victims who marry or reconcile outside the Islamic religious court as referred to in paragraph (2) may be subject to a tariff of Rp. 0.00 (zero rupiahs); (4) Further provisions regarding the terms and procedures are subject to a Rp tariff. 0.00 (zero rupiahs) to economically incapable citizens and 
disaster victims ${ }^{7}$ who carry out marriage or reconciliation outside the District Islamic religious court, as mentioned in paragraph (1). paragraph (3) is regulated by a Regulation of the Minister of Religion after coordinating with the Minister of Finance. ${ }^{8}$

Based on the explanation above, there are several solutions to prevent the practice of underhand marriage by the Government, one of which is through PP 48 of 2014 concerning Marriage Fees. Marriages performed outside the Islamic religious court are subject to a fee of $\mathrm{Rp}$. 600,000, - and weddings. conducted at the Islamic religious court is subject to a fee of Rp. 0,- (Free), in this case, the Government provides choices to the community, especially for those who cannot afford it. It is one of the preventive measures and solutions from the Government to facilitate the community and reduce the number or practice of underhanded marriages.

In terms of costs, the Government also provides access to marriage services at Islamic religious courts by using an easier, cheaper, and more efficient system.

In 2016 there were 150 pairs of unregistered marriage in two sub-

${ }^{7}$ Handayani, A. M. S., \& Nurdin, N. (2021). Understanding Women's Psychological WellBeing in Post-Natural Disaster Recovery. Medico Legal Update, 21(3), 151-161.

${ }^{8}$ Khoirul Anwar, SHI, "PP 482014 dan PMA 24 2014, Menuju KUA Berintegritas” Bimasislam online. $25 \quad$ September 2014. https://bimasislam.kemenag.go.id/post/opini/pp-482014-dan-pma-24-2014-menuju-kua-berintegritas (12 Januari 2019) districts in Sigi Regency, namely Marawola Subdistrict and Kinovaro Subdistrict, which had an Integrated Marriage Isbat Session in 2017 and in collaboration with the Ministry of Religion of Sigi Regency, the Donggala Regency Religious Court, and the Population and Population Office. Civil Registry of Sigi Regency in implementing the Integrated Marriage Certificate, Isbat Marriage Books, and Acceptance of Family Cards and Identity Cards for 150 pairs of Marawola and Kinovaro Subdistricts who do not yet have a marriage book and Family Card and Identity Card. ${ }^{9}$

Based on these data, the author wants to conduct research on a sociological review of unregistered marriages, especially those that occur in the Marawola District, because based on initial observations made by researchers in the Marawola District area, there are still many people who practice underhand marriage for various reasons. So the author wants to do research on how the practice of underhand marriage, the factors that cause it, and the sociological impact on the practice of unregistered marriage in the Marawola District, Sigi Regency.

\section{Literature Review}




\subsection{Unregistered Marriage according to Islam}

In the event of a marriage, legal norms and regulations are needed to regulate it. The application of legal norms in the event of marriage is especially needed to regulate the rights, obligations, and responsibilities of each family member to form a happy, eternal, and prosperous household. In society, we see a marriage pattern that is wrapped in religious law. However, its soul is contrary to religious teachings, and a western marriage pattern contrary to the Indonesian people's way of life, as well as a marriage pattern according to customs which would no longer be in accordance with the development of society and society. Progress of the times. The intended marriage patterns are; forced marriages, marriages of minors, marriages that are too easy, polygamous marriages freely, and illegal marriages. ${ }^{10}$

The enactment of the marriage law does not necessarily eliminate completely the practice or pattern of marriage that is not in accordance with state legal procedures. Article 2 paragraph (1) of the Marriage Law states that "Marriage is legal if it is carried out according to the law of each religion and belief."11 The understanding of this article gives birth to various perceptions regarding marriages being legal as long as the law according to their religion has been declared valid. In Islamic law, marriage

\footnotetext{
${ }^{10}$ Riduan Syahrani, Perkawinan dan Perceraian Bagi Pegawai Negeri Sipil. (Jakarta: PT. Media Sarana Press, Cetakan I, 1987)

${ }^{11}$ Indonesia, Undang-Undang Perkawinan No. 1 Tahun 1974 Tentang Perkawinan, Pasal 2 ayat (1).
}

is valid if the conditions and pillars are met.

The terms and pillars of marriage in Islamic religious law do not include marriage registration as a legal requirement for marriage, while Article 2 paragraph (2) of the Marriage Law states that "Every marriage is recorded according to the applicable laws and regulations."12 From the 2 (two) paragraphs in Article 2 of the Marriage Law, a legal debate arises regarding the validity of marriages that have been carried out according to religious teachings but are not recorded in legal documents in the state. The result of this problem is the existence of marriages that are legal according to religion but do not get legality according to state law. Thus, the rights and obligations between husband and wife are not fully guaranteed by the state. In connection with the various problems that arise from the pattern of marriage, then in this study, the author wants to examine more deeply unregistered marriages.

According to the language of marriage, unregistered marriage means a marriage carried out in secret or a secret marriage. Meanwhile, according to the law, an underhand marriage is a marriage that can be declared legally valid (if the conditions and pillars are fulfilled) but have no legal force.

According to Idris Ramulyo, $\mathrm{SH}$, unregistered marriage is a marriage carried out by Indonesian Muslims, fulfilling both the pillars and the conditions of marriage, but not being

${ }^{12}$ Idib., Pasal 2 ayat (2)

e-ISSN: 2715-4580 p-ISSN: 2715-8268 
registered with the Marriage Registrar, as regulated, and determined by Law Number 1 of $1974 . .^{13}$

In a private marriage, the marriage registrar (KUA) will not record the marriage because it is considered to deviate from the applicable law. ${ }^{14}$ As a result, married couples will not get a marriage certificate. Even if you get a marriage certificate, there are two possibilities. The first is the original but fake marriage certificate, which is a marriage certificate owned by the community but not registered with the KUA. The second is that the KUA officers in a coalition are KUA officers who violate the rules regarding marriage registration by issuing a marriage certificate but do not register the marriage.

Meanwhile, the Indonesian legal system does not recognize the term unregistered marriage and the like. However, sociologically this term is given to marriages that are not registered and do not meet the provisions of the applicable law. In particular, regarding the registration of marriages regulated in Law No.1 of 1974 concerning Marriage, article 2 paragraph (2) emphasizes that marriages must be recorded in

\footnotetext{
${ }^{13}$ Idris Ramulyo, Tinjauan Beberapa Pasal Undang-Undang No. 1 Tahun 1974 Dari Segi Hukum Perkawinan Islam. (Jakarta: Ind-Hill-Co, 1990), 226

14Lembaga Bantuan Hukum APIK, Artikel Dampak Pernikahan Bawah Tangan Bagi Perempuan, online 14 Juli 2011, http://www.lbhapik.or.id/fact51-bwh/20tangan.htm (11 Januari 2019)
}

accordance with the provisions of the applicable laws. ${ }^{15}$

From the description above, it can be concluded that unregistered marriage is a marriage that has fulfilled the requirements and pillars of Islamic law. But it does not follow state law that requires it to be recorded.

\subsection{The lawlessness that Occurs in Unregistered Marriages}

An unregistered marriage is a marriage that is done without registration. The existence of this marriage registration is a form of state concern for the readiness and maturity of the couple in building a family later. That is why the state makes laws regarding marriage in the form of Law Number 1 of 1974.

In the modern era, the only acceptable understanding of the law is the state's law made or enforced, or accepted into force. So that the state element is an absolute element for the existence of modern law. ${ }^{16}$

The rule of law is different from other rules. Weber argued that law has three basic characteristics that distinguish it from other rules. ${ }^{17}$

In relation to the marriage law that applies in Indonesia is the ineffectiveness of the law itself. This is because there is no force that forces people to obey marriage law. Whereas the normative

${ }^{15}$ Subekti, Kitab Undang-undang Hukum Perdata, Cet.1, (Jakarta: PT Pradnya Paramita, 2009), 538

${ }^{16}$ Muh. Akbar Habe, Pengantar Ilmu Hukum (Makassar: Pustaka Refleksi, 2010), 29

${ }^{17} \mathrm{Ibid}$. 
legal system must contain the existing elements ${ }^{18}$

The absence of strict sanctions, coercive rules, and ambiguous recording rules creates a dualism of understanding in the Marriage Law makes unregistered marriages rife in society. Even though the Marriage Law is a legal product that has been born since 1974, even the Law on Marriage Registration has existed since 1954. However, its practice still always deviates from the rules contained in it.

Factors of Unregistered Marriages In practice, unregistered marriages that occur in the community are like an iceberg phenomenon, many occur in society, but only a few appear to the surface. unregistered marriages that often appear in the news are those who are actors or state officials. ${ }^{19}$ This happened not only because of the indecisive and ambiguous factors of the marriage law but also due to various factors. 20

Economic factors include administrative costs of marriage registration, whereas some people, especially the lower middle class, feel that they cannot pay for the registration

Indonesia, 117

18Muhammad Sodiq, "Dualisme Hukum di

${ }^{19}$ Siti Ummu Adilah, "Analisis Hukum terhadap Faktor-Faktor yang Melatarbelakangi Terjadinya Nikah Sirri dan Dampaknya Terhadap Perempuan (Isteri) dan Anak-anak," Jurnal Dinamika Hukum 11, Edisi Khusus (Februari 2011), 105

20Siti Ummu Adilah, "Analisis Hukum terhadap Faktor-Faktor yang Melatarbelakangi Terjadinya Nikah Sirri dan Dampaknya Terhadap Perempuan (Isteri) dan Anak-anak, 106-108 administration, which sometimes swells to twice the official cost. In addition, the existence of a community custom where the obligation of men to pay dowries, bear the costs of the wedding party, and other traditional events that cost quite a lot of money is a reason for men who are not yet economically established to marry secretly without being registered..$^{21}$

Factors that are not old enough to makes unregistered marriages a solution. The bride and groom are not yet old enough to get married in the Marriage Law, which makes them think about getting married without having to record unregistered marriages. 22

Factors of official/work or school ties. A few official/work ties or school regulations do not allow marriage because she works for a certain time according to the agreed agreement, or because she is still in school, she is not allowed to marry until she graduates. If you get married later, you will be expelled from work or school because it is considered to have violated the rules. ${ }^{23}$

There is an assumption that unregistered marriages are legal according to religion, while recording is only administratively orderly. ${ }^{24}$ Pregnancy outside of marriage is an effect of promiscuity. The result of promiscuity between men and women, who no longer heed the norms and religious rules, is pregnancy outside of marriage. A pregnancy that occurs is a

21Ibid., 110

22Ibid., 112

${ }^{23}$ Ibid., 113

${ }^{24}$ Ibid. 
disgrace to the family and will invite society's mockery, where parents marry off their children in secret and without recording with the man who got her pregnant with the excuse of saving the family's good name. ${ }^{25}$

Lack of public understanding ${ }^{26}$ and awareness about marriage registration resulted in people who still often carry out unregistered marriages. There is an assumption that marriages that are recorded and not recorded are the same. ${ }^{27}$

Social factors, namely people who have already given a negative stigma to men who are married more than one (polygamy), so to avoid this negative stigma, unregistered marriages is a solution to carry out polygamy. ${ }^{28}$

There are difficulties and rules of polygamy. For a second, third, and so on (polygamy), marriage has several conditions that must be met, according to the polygamy requirements described in Article 5 of the Marriage Law, which must obtain permission and approval from the previous wife. This is expected to reduce the occurrence of polygamy for any reason. And because it is difficult to get permission from the first wife, secret marriage is a possible solution for them. ${ }^{29}$

\footnotetext{
25Ibid., 114

${ }^{26}$ Ermawati, E., Musyahidah, S., \& Nurdin, N. (2021). Muslim Society Perspective on Islamic Banking Corporate Social Responsibility in Indonesia (Based On Qur'an and Hadits Economic Themes). International Journal of Business and Management Review, 9(3), 29-40.

${ }^{27}$ Ibid., 115

${ }^{28}$ Ibid., 116

${ }^{29}$ Ibid., 117
}

In the absence of firm action from the government, many people still carry out unregistered marriages. Without legal action from the authorities, the community will assume that it is okay to do unregistered marriages so that people will continue, and many will continue to do the weddings.t. ${ }^{30}$

These factors indicate that marriage rules in Indonesia are still difficult to be accepted absolutely by the community. Therefore, they prefer to use religious law as the basis for the implementation of marriage, without assuming that marriage recognized by the state is a must that must be owned in building a family.

From these factors, it can also be seen that, in general, the implementation of unregistered marriages is carried out because there are rules that cannot be fulfilled and must be violated. Hence, they prefer to carry out unregistered marriages.

\section{Methodology}

This study uses qualitative approach $^{31,32}$ investigating the sociologies perspectives on unregistered

\footnotetext{
${ }^{30}$ Ibid., 118

31 Nurdin, N., \& Yusuf, K. (2020). Knowledge management lifecycle in Islamic bank: the case of syariah banks in Indonesia. International Journal of Knowledge Management Studies, 11(1), 59-80. https://doi.org/10.1504/ijkms.2020.105073

${ }^{32}$ Nurdin, N., Stockdale, R., \& Scheepers, H. (2014). Coordination and Cooperation in EGovernment: An Indonesian Local E-Government Case The Electronic Journal of Information Systems in developing Countries, 61(3), 1-21.
} 
marriages. This study was carred out in Marawola district in Central Sulawesi Indonesia. This study also used sociological approach in understanding social impact on families with unregistered marriages. Data were collected through field observation, indepth interviewes with under age's unregistered marriage families' members. Written materials were also used to analyze the case. ${ }^{33} \mathrm{We}$ also interviewed divorced families' members who practiced unregistered marriage before they divorced to understand their experiences. Data analysis consists of several procedures which included reduction and verification techniques with various data sources. ${ }^{34}$ The reduced data is then analyzed reflecting on theoretical concepts used in this study ${ }^{35}$.

\section{Result and Discussion}

\subsection{The Practice of Unregistered Marriages in Marawola District}

33 Nurdin, N. (2018). Institutional Arrangements in E-Government Implementation and Use: A Case Study From Indonesian Local Government. International Journal of Electronic Government Research (IJEGR), 14(2), 44-63. https://doi.org/10.4018/ijegr.2018040104

34 Muslih, Imam, Nurdin, Nurdin, \& Marzuki, Marzuki. (2020). Effectiveness of Marriage Services Through Information System Management (SIMKAH) at Palu City Religious Court International Journal of Contemporary Islamic Law And Society, 2(1), 20-35.

35 Iqbal, M., Rusli, R., \& Musyahidah, M. (2019). Management Strategies of Professional Zakat Funds for Mustahiq Family Welfare By Amil Zakat Body International Journal of Contemporary Islamic Law And Society, 1(1), 39-51.
The term "unregistered marriages" emerged after Law No.1/1974 on marriage became effective on October 1 , 1975. Underhand marriage is the opposite of what is done according to law. Meanwhile, according to the law, marriage is regulated Marriage Law. Therefore, it can be formulated that an unregistered marriage is a marriage that is not carried out according to the law. And marriages that are not carried out according to the law are considered illegal marriages, so they have no legal consequences. ${ }^{36}$

Unregistered marriages are marriages that are carried out according to Syariah law. But are not carried out in the presence of a Marriage Registrar as an official government official and are not registered at the Islamic religious court, so that they do not obtain a Marriage Certificate as the only formal legal evidence. ${ }^{37}$ While KH. Ma'ruf Amin said that unregistered marriages is a marriage that fulfills all the pillars and conditions stipulated in fiqh (Islamic law). However, this marriage is without official registration at the authorized institution as regulated in the legislation. ${ }^{38}$

${ }^{36}$ Darmawati, Nikah Siri, nikah dibawah tangan dan status anaknya, Ar-Risalah, 6 No.1, (Mei 2010), 38-39

${ }^{37} \mathrm{H}$. A Zahri,"Argumentasi Yuridis Pencatatan Perkawinan Dalam Perspektif Hukum Islam".http:// badilag.net/data/ARTIKEL/Argu mentasi\%20Yuridis\%20Pencatatan\%20Perkawina n\%20dlam\%20Perspektif\%20Hukum\%20Islam.pd f. (01 Juni 2019)

${ }^{38 H u k u m}$ Online, "Nikah dibawah tangan: Pencatatan Nikah Akan Memperjelas Status Hukum". http://www.hukumonline.com/berita/baca/hol e-ISSN: 2715-4580 p-ISSN: $2715-8268$ 
In contemporary fiqh, unregistered marriages are known as zawaj 'urfi, which is a marriage that meets the requirements of marriage but is not officially registered by an Islamic religious court staff who handles marriage. It is called 'urfi marriage because this marriage is a custom and habit that has been running in Muslim society since the time of the Prophet Muhammad and his noble companions, where they do not need to record their marriage contract without any problems in their hearts.. ${ }^{39}$

The widespread practice of unregistered marriages is evidence that the majority of Indonesian people still do not understand the function and consequences of unregistered marriages. Based on the facts of the marriage that occurred, recording is not just carrying out administrative order as referred to in Article 5 paragraph (1) of the KHI but has implications for the legal identity of the marriage, the heirs, and the identity of the child. However, national legal politics still places marriage registration as a guarantee of administrative order and legal certainty, not the validity of marriages. It is also emphasized in the KHI academic text that the creation of order related to state administration is expected to lead to the creation of social order; marriage events can be controlled

15651/pencatatan-nikah-akanmemperjelasstatus-hukum (02 Juni 2014)

${ }^{39} \mathrm{Ahmad}$ bin Yusuf ad-Daryuwisy, AzZawaj Al-'Urfi, (KSA: Darul Ashimah, Cet I. 1426 H). 21 so that no parties (especially women) are harmed. 40

Based on the results of field research conducted through interviews with informants, data were obtained about the practice of unregistered marriages that occurred in the Islamic religious court area, Marawola District, Sigi Regency, and researchers obtained interview data from several informants. For example, one of the informants said:

"I am a divorced man, and I have 2 (two) children from my first marriage, then on June 22, 2015, At 10:00 WITA, I remarried a woman with the initials "Ja," 50 years old, Islam, primary school education (SD), household chores, widowed status, and death, has 4 (four) children from his first marriage, resides in South Tinggede Village." 41

Their wedding took place at the house of her husband's parents in a village with a very simple event, inviting several local residents. The guardian of "Ja" is the son of his father's brother's uncle and witnessed by two male witnesses, each from our family, with a dowry of Rp. 110,000 (one hundred and ten thousand rupiahs).

The informant also said that she and her husband married under the hands to avoid Zina. They do not know the marriage procedure at Islamic religious court. The child of the husband does not approve of her marrying her

\footnotetext{
40Ninik Rahayu, "Politik Hukum Itsbat Nikah," Musawa 12, No. 2 (Juli 2013), 283

${ }^{41} \mathrm{Hn}$, Wiraswasta, Wawancara Pribadi, Kantor KUA Marawola, 20 Juni 2019

e-ISSN: 2715-4580 p-ISSN: $2715-8268$
} 
husband on the grounds that he is still young. According to him, their marriage was legal according to religion, namely the fulfillment of the pillars and conditions of marriage, of their own volition and without coercion from other parties. The marriage was carried out on a consensual basis, but he was aware that their marriage was not registered at the Islamic religious court office. ${ }^{42}$

The informant also said that after getting married, they wanted to apply for a new Identity Card and Family Card. However, they did not have a marriage book because the marriage was not registered at the Islamic religious court, so they could not apply for a National Identity Card. And Family Card. 43

Another male informant said the following:

"I am a young man. On September 25, 2015, At 11:00 WITA, I married a woman with the initials SS, 42 years old, Islamic religion, junior high school education (SMA), housework, virgin status, and resides in South Tinggede Village." 44

Their wedding took place at the house of his wife's parents in a village with a very simple event that only invited a few families and local residents. His wife's guardian was his own father, and two witnesses from his wife's family witnessed a dowry of Rp. 110,000 (one hundred and ten thousand rupiah). ${ }^{45}$

\footnotetext{
${ }^{42}$ Ibid.,

43Ibid.,

${ }^{44}$ So dan SS, Wiraswasta dan Ibu Rumah

Tangga, Wawancara Pribadi, Kantor KUA Marawola, 20 Juni 2019

${ }^{45}$ Ibid.,
}

The informant also said that he and his wife is an unregistered marriage because his family, namely his uncle and aunt, did not approve of their marriage on the grounds that he did not have a steady job and to avoid Zina. The marriage was also carried out to maintain the family's good name because they already liked each other, so they decided to have a wedding even though it had not been recorded at the Islamic religious court. They also do not know how to get married in an Islamic religious court. At that time, the most important thing was that their marriage was legal according to religion because the pillars and conditions of marriage had been fulfilled.

The informant and his wife said they realized that their marriage was not registered at the Islamic religious court, so they could not apply for Identity Cards and Family Cards. Then they said when they got a job, the siduami would invite his wife to live with him at work.

\section{Factors That Cause Unregistered Marriages \\ Based on the results of field} research conducted through interviews with informants, data were obtained about the factors causing the practice of unregistered marriages in the Marawola District. In contrast, the contributing factors included a lack of understanding and public awareness about the importance of marriage registration.

As explained by the interviewees, that of the five pairs of sources providing an explanation of their understanding that it is important that they are married and legally married, the matter of e-ISSN: 2715-4580 p-ISSN: $2715-8268$ 
registration of marriages is only administratively orderly.

Even though the law has provided an explanation of the importance of registering marriages, recording is regulated because without recording, a marriage has no legal force. As a result, if one of the parties neglects their obligations, the other party cannot take legal action because they do not have valid, authentic evidence of the marriage they are carrying out. In addition, recording also has preventive benefits, namely to prevent or prevent deviations from the pillars and conditions of marriage, both according to the law of religion and belief and legislation. ${ }^{46}$

Marriage, hereinafter referred to as marriage, is an institution that gives legitimacy to a man and woman to be able to live and gather together in a family. The peace or tranquility of a family is determined, one of which is that the marriage must be in accordance with the demands of Islamic law (for Muslims). In addition, there are other rules that stipulate that marriages must be registered at the Islamic religious court/Civil Registry. ${ }^{47}$

Marriage registration, in principle, is a basic right in the family. Besides that, it is an effort to protect the wife and children by obtaining family rights such as inheritance rights and others. In the case of underhanded marriages or marriages that are not registered in the

Nikah,

${ }^{46}$ KUA Pringsurat, Pentingnya Pencatatan

http:/ / kuapringsurat.blogspot.com/2015/03/pe ntingnya-pencatatan-nikah.html, (01 Juli 2019) 47 Ibid., state administration resulting in women not have legal force in the rights of childcare status, inheritance rights, and other rights as the right wife, ultimately very detrimental to women.

This is possible because the socialization of marriage registration has not been maximized, and has not touch all levels of society, especially parents and young brides, with very minimal public understanding of the importance of marriage registration, consequently affecting the community so that they continue to carry out unregistered marriages even though it has been explained in Article 2 paragraph (1) of Law Number 1 of 1974.48

Another factor that causes unregistered marriages is that no one wants to take firm action. In Government Regulation Number 9 of 1975 concerning the Implementation of Law Number 1 of 1974 concerning Marriage, Article 45 states that whoever violates the provisions stipulated in Article 3, 10 paragraph (3), 40 of this Government Regulation shall be punished with a maximum fine of Rp. 75.00 (Seven Thousand Five Hundred Rupiah). Then Registrar employees who violate the provisions stipulated in Article 6, 7, 8, 9, 10 paragraphs (1), 11, 13, 44 of this Government Regulation shall be punished with imprisonment for a maximum of 3 (three) months or a fine of up to Rp. 75.00 (Seven Thousand Five Hundred Rupiah). Furthermore, in

\footnotetext{
${ }^{48}$ Republik Indonesia, Undang-Undang Nomor 1 Tahun 1974 tentang Pernikahan, Pasal 2 ayat (1)

e-ISSN: 2715-4580 p-ISSN: $2715-8268$
} 
paragraph (1) above, the crime referred to is a violation. ${ }^{49}$

There is an assumption that unregistered marriages are legal according to religion. While marriage registration is only administratively orderly, almost all sources have the same reason.

Premarital pregnancy is the effect of promiscuity. The result of promiscuity between men and women, who no longer heed the norms and religious rules, is pregnancy outside of marriage. A pregnancy that occurs, is a disgrace to the family which will invite the negative stigma of society. This is where parents marry off their children in secret and without recording with the man who got her pregnant with the excuse of saving the family's good name, as happened to the informant above.

Many people do not want to arrange marriages directly to the Islamic religious court and still use third parties, so that the prospective bride and groom do not get direct information from the Islamic religious court about the lack of marriage administration files that they still have to complete to fulfill the administrative requirements for marriage registration.

Furthermore, there are parties or religious figures who help the community to carry out unregistered marriages so that people feel confident because they are indirectly supported by

${ }^{49}$ Republik Indonesia, Peraturan Pemerintah Nomor 9 Tahun 1975 tentang Pelakanaan Undang-Undang Nomor 1 Tahun 1974, Pasal 45 ayat (1) dan (2) these individuals who dare to violate the rules regarding marriage registration.

Finally, unregistered marriages can also occur because they were unable to fulfill the administrative requirements demanded by the Islamic religious court. After the prospective married couple is unable to meet the complicated requirements for economically disadvantaged couples, they prefer to get unregistered marriage.

\section{Conclusions}

The practice of unregistered marriage that occurred in the Marawola sub-district is perceived by some people who practice unregistered marriage as a marriage that is only based on religious provisions but is not recorded in the Islamic religious court, because according to some people who practice unregistered marriages, that unregistered marriages is a practical solution option to justify the relationship between husband and wife for various reasons including when there are obstacles in the provisions of the marriage registration procedure, ignorance of marriage procedures and due to pregnancy outside of marriage and in order to avoid adultery and because of the presence of other parties and those who did not approve of the marriage taking place.

Therefore, so that the community continues to carry out marriages carried out by the village priest on the grounds that the time for the wedding has been determined and the invitations have been circulated, the most important thing according to them is that the pillars and conditions of marriage have been e-ISSN: 2715-4580 p-ISSN: 2715-8268 
fulfilled so that the marriage continues to be carried out. Registered at the religious court. Because according to them, marriage registration is only formal legality.

The causes of the practice of unregistered marriages in the Marawola sub-district include ignorance of the procedure for registering marriages in the religious court to avoid adultery because it has fulfilled the pillars and conditions of marriage so that it is legal according to religion, to cover the shame of the family when pregnancy occurs outside marriage, non-fulfillment of marriage registration procedures, family parties who do not agree, and the presence of unscrupulous members of the community who assist in the unregistered marriages process. This is a factor in the occurrence of unregistered marriages in the Marawola District.

\section{REFERENCES}

Adang, Yesmil Anwar. Pengantar Sosiologi Hukum, (Jakarta: PT. Grasindo, 2008)

Amin, Ma'ruf. Fatwa MUI sejak 1975. (Jakarta: Penerit Erlangga, 2011)

Aminuddin, Slamet Abidin. Figh Munakahat 1, (Bandung: Pustaka Setia, 1999)

Ahmad, Abd Kadir. Hukum Perkawinan Islam Indonesia (Jakarta:Kencana, 2006)

Ali, Zainuddin. Hukum Perdata Islam di Indonesia (Cet. II; Jakarta: Sinar Grafika, 2007)

Adilah, Siti Ummu, "Analisis Hukum terhadap Faktor-Faktor yang Melatarbelakangi Terjadinya Nikah
Sirri dan Dampaknya Terhadap Perempuan (Istri) dan Anak-anak," Jurnal Dinamika Hukum 11, Edisi Khusus (Februari 2011)

Atsar ID, "Menulis / Mencatat Ilmu adalah Sunnah Rasulullah", Official Website Atsar ID (https://www.atsar.id/2017/03/ menulis-mencatat-ilmu-adalahsunnah-nabi.html), (18 Januari 2019)

Ahmad, A. Rahmata Rosyadi, M. Rais. Formalisasi Syariat Islam dalam Perspektif Tata Hukum Indonesia (Bogor: Ghalia Indonesia, 2006)

Arifin, Imron. Penelitian Kualitatif dalam Ilmu-Ilmu Sosiala dan Keagamaan (Cet III; Malang: Kalimasada Press, 1996)

Ahmad Sanusi, "Pelaksanaan Isbat Nikah di Pengadilan Agama Pandeglang," Ahkam 16, No. 1 (2016)

Bungin, Burhan. Penelitian Kualitatif, Komunkasi, Ekonomi, Kebijakan Publik, dan ilmu Sosial lainnya, (Ed. I, Cet. I; Jakarta: Kencana Prenada Media Group, 2007)

Bimais Kemenag RI, https:// bimasislam.kemenag.go.i $\mathrm{d} /$ index.php?option $=$ com_content \&view $=$ article $\&$ id $=313 \&$ catid $=49 \%$ 3Aartikel\&Itemid $=79$, (08 Juni 2019)

Basuni, "Perkawinan Tidak Tercatat", http://basunibahmidpanjaitan.blogspot.com/2017/0 7/perkawinan-tidak-tercatat.html (08 Juni 2019)

Dr. H. Habiburrahman, M. Hum, Anak Luar Nikah dalam Putusan Mahkamah Konstitusi, dalam Varia

e-ISSN: $2715-4580$ p-ISSN: 2715-8268 
Peradilan Nomor 317 April 2012, (Jakarta: IKAHI)

Darmawati, Nikah Siri, nikah dibawah tangan dan status anaknya, ArRisalah, 6 No.1, (Mei 2010)

Dya, Riady. Pegertian Tinjuan, https://www.scribd.com/docum ent/355871983/PengertianTinjauan-Tinjauan-AdalahPemeriksaan-Yang-Teliti, (29 Januari 2019)

Departemen Agama RI, Al-Qur'an dan terjemahnya (Surabaya: CV Karya Utama,2005)

Djazuli, A. Kaidah-Kaidah Fikih (Cet. V; Jakarta: Kencana PrenadaMedia Group, 2014)

Ermawati, E., Musyahidah, S., \& Nurdin, N. (2021). Muslim Society Perspective on Islamic Banking Corporate Social Responsibility in Indonesia (Based On Qur'an and Hadits Economic Themes). International Journal of Business and Management Review, 9(3), 29-40.

Ezmir, Metodologi Penelitian Kualitatif Analisis Data (Jakarta; PT. Raja Grafindo Persada, 2011)

Fauzi, "Sigi Komitmen Permudah Pengurusan Buku Nikah", Antara Sulteng Online. 27 Februari 2018. https:// sulteng.antaranews.com/ berita/39540/di-sigi-tiga-instansikomitmen-permudahpengurusan-buku-nikah $(10$ Januari 2019)

Feener, Mark E. Cammack dan R. Michael. The Islamic Legal System In Indonesia, Pacific Rim Law \& Policy Journal 21, No. 1 (2012)
Fatwa Majelis Ulama Indonesia, Nikah Di Bawah Tangan. Nomor 10 Tahun 2008 (Jakarta: 17 September 2008)

Feener, Mark E. Cammack dan R. Michael. The Islamic Legal System In Indonesia, Pacific Rim Law \& Policy Journal 21, No. 1 (2012)

Gusrianto, Tinjauan Sosiologis Terhadap Pernikahan di Bawah Tangan (Studi Kasus di Dusun Gonjen, Desa Tamantirto, Kecamatan Kasihan, Kabupaten Bantul, Daerah Istimewa Yogyakarta), (Yogyakarta: UIN Sunan Kalijaga Yogyakarta, 2016)

Hasan Ali, Pedoman Hidup Rumah Tangga dalam Islam, Cet.1, (Jakarta: Siraja, 2003)

Hakim, Rahmat. Hukum Perkawinan Islam untuk IAIN, STAIN, PTAIS (Bandung: CV Pustaka Setia, 2000)

Hamza, Ali. Kinerja Penyuluh Agama Non PNS Kementerian Agama, Jurnal Islamika: Jurnal Ilmu Keislaman 18 No. 2 (Desember, 2018)

Handayani, A. M. S., \& Nurdin, N. (2021). Understanding Women's Psychological Well-Being in PostNatural Disaster Recovery. Medico Legal Update, 21(3), 151-161.

Henslin, James M. Sosiologi dengan pendekatan membumi, edisi 6 jilid 1, (PT. Gelora Aksara Pratama, 2006)

Habe, Muh. Akbar. Pengantar Ilmu Hukum (Makassar: Pustaka Refleksi, 2010)

Hubarman, Mattew B Miles dan A. Michael. Qualitatif data Analisis, diterjamahkan oleh Tjecep Rohendi, Analisis Data Kualitatif. Buku Tentang Metode-Metode Baru, (Cet. I; Jakarta : UI Press, 2005) 
Hadi, Sutrisno. Metedologi Reseach, untuk Penulisan Paper, Skripsi, Tesis dan Disertasi, (Jilid II; Cet. X. Yogyakarta: yayasan Penerbit Fakultas psikologi Universitas gajah Mada, 1981)

Hukum Online, "Nikah dibawah tangan: Pencatatan Nikah Akan Memperjelas Status Hukum".http://www.hukumonli ne.com/berita/baca/hol15651/pe ncatatan-nikah-akanmemperjelasstatus-hukum (02 Juni 2014)

al-Jaziri, Abdurahman. Al-Fiqh 'Alā Mażāhib Al-'Arba'ah Juz 4,(t.p: Dar El-Hadits, 2004)

Jones, Pip, Pengantar Teori-Teori Social: Dari Teori Fungsionalisme Hingga Post-Modernisme, (trj). Safiuddin (Jakarta: Pustaka Obor, 2003),

Kitab Hadis Digital 9 Imam Lidwa Pustaka Offline (Shahih Bukhari, 6644)

Kompilasi Hukum Islam (KHI) Psal 5 ayat 2, pasal 6 ayat 2 pasal ayat 1 .

Kaelany HD, Islam dan Aspek-Aspek Kemasyarakatan Edisi Kedua (Jakarta: Bumi Aksara, 2000)

Kementerian Agama RI, "Pencarian Akta Nikah". Official Website Sistem Informasi Manajemen Nikah Kementerian Agama RI. http://simkah.kemenag.go.id/asli .php?panel=4 (28 Januari 2019)

Latif, Nasarudin. Ilmu Perkawinan : Problematika Seputar Keluarga dan Rumah Tangga, (Jakarta: Pustaka Hidayah, 2001 Cet 1)

Matnuh, Harpani. Perkawinan Di bawah tangan Dan Akibat Hukumnya Menurut Hukum Perkawinan
Nasional, Jurnal Pendidikan Kewarganegaraan, 6 No. 11 (2006) Masruhan, "Pembaruan Hukum Pencatatan Perkawinan di Indonesia Perspektif Maqasid Al-Shari'ah" Al-Tahrir 13, No. 2 (November 2013)

Moleong, Lexy J. Metodologi Penelitian Kualitatif (Cet XII; Bandung Remaja Rosdakarya, 2002)

Margono, S. Metodologi Penelitian Pendidikan (Cet II; Jakarta: Rineka Cipta, 2000)

Muslih, I., Nurdin, N., \& Marzuki, M. (2020). Effectiveness of Marriage Services Through Information System Management (SIMKAH) at Palu City Religious Court INTERNATIONAL JOURNAL OF CONTEMPORARY ISLAMIC LAW AND SOCIETY, 2(1), 20-36.

Musyahidah, S., Ermawati, E., \& Nurdin, N. (2021). The Effect of Riba Avoidance and Product Knowledge on the Decision to Become a Customer of Islamic Banks. International Journal of Multidisciplinary Research and Analysis, 4(8), 1090-1101.

Nasir, M., Abidin, Z., \& Thahir, L. S. (2021). Pre-Marital Counseling Effectiveness In Building Happy Muslim Families INTERNATIONAL JOURNAL OF CONTEMPORARY ISLAMIC LAW AND SOCIETY, 3(1), 56-68.

Nur, Djamaan. Figh Munakahat (Semarang: CV. Toha Putra, 1993)

Nurdin, N., Stockdale, R., \& Scheepers, H. (2014). Coordination and Cooperation in E-Government: An Indonesian Local E-Government Case The Electronic Journal of e-ISSN: 2715-4580 p-ISSN: 2715-8268 
Information Systems in developing Countries, 61(3), 1-21.

Nurdin, N. (2018). Institutional Arrangements in E-Government Implementation and Use: A Case Study From Indonesian Local Government. International Journal of Electronic Government Research (IJEGR), 14(2), 44-63. https:// doi.org/10.4018/ijegr.2018 040104

Nurdin, N., \& Yusuf, K. (2020). Knowledge management lifecycle in Islamic bank: the case of syariah banks in Indonesia. International Journal of Knowledge Management Studies, 11(1), 59-80. https:// doi.org/10.1504/ijkms.2020 .105073

Noor, Juliansyah. Metodologi penelitian Skripsi, Tesis, Disertasi, dan Karya Ilmiyah, (Cet. II; Jakarta: Kencana Prenada Media Group, 2012)

Republik Indonesia, Undang-undang Nomor 1 Tahun 1974 tetang Perkawinan, bab I, pasal 1

Republik Indonesia, Undang-Undang Nomor 1 Tahun 1974 tentang Pernikahan, Pasal 2 ayat (1)

Republik Indonesia, Peraturan Pemerintah Nomor 9 Tahun 1975 tentang Pelakanaan Undang-Undang Nomor 1 Tahun 1974, Pasal 45 ayat (1) dan (2)

Ramulyo, Idris. Tinjauan Beberapa Pasal Undang-Undang No. 1 Tahun 1974 Dari Segi Hukum Perkawinan Islam. (Jakarta: Ind-Hill-Co, 1990)

Rasjid, H. Sulaiman. Figh Islam (Bandung: Sinar Baru Algensindo; Cetakan ke 42, 2009)
Rahayu, Ninik. "Politik Hukum Itsbat Nikah," Musawa 12, No. 2 (Juli 2013)

Syahrani, Riduan. Perkawinan dan Perceraian Bagi Pegawai Negeri Sipil. (Jakarta: PT. Media Sarana Press, Cetakan I, 1987)

Shadily, Hasan. Sosiologi Untuk Masyarakat Indonesia, (Jakarta: Bina Aksara,1983), Cet. IX

Sabiq, Sayyid Fiqh Sunnah, Juz VI, (Bandung: PT. Al Ma'arif, 2000),

Soekanto, Soejono. Sosiologi Suatu Pengantar, (Jakarta:CV Rajawali,1982), Cet. 1

Sodiq, Muhammad. "Dualisme Hukum di Indonesia:Kajian tentang Peraturan Pencatatan Nikah dalam PerundangUndangan" Al-Ahwal 7, No. 2 (2014)

Syarifuddin, Amir. Hukum Perkawinan Islam di Indonesia Antara Figh Munakahat dan Undang-Undang Perkawinan (Cet. III; Jakarta: Kencana Prenada Media Group, 2009)

Syahuri, Taufiqurrohman. Legislasi Hukum Perkawinan di Indonesia ProKontra Pembentukannya hingga Putusan Mahkamah Konstitusi, (Jakarta: Kencana Prenada Media Group, 2013)

Sari, Henny Rachma. "25 Persen Masyarakat Indonesia Melakukan Nikah Siri", Merdeka Online. 26 Desember 2012. https://www.merdeka.com/peris tiwa/25-persen-masyarakatindonesia-melakukan-nikahsiri.html, (10 Januari 2019)

Subarman, Munir. Nikah di Bawah Tangan Prespektif Yuridis dan Sosiologis, e-ISSN: $2715-4580$ p-ISSN: 2715-8268 
International Journal of Contemporary Islamic Law and Society

Vol. 3 No. 2 Tahun 2021

Jurnal Wawancara Hukum Islam 13, No.1 (Juni, 2013)

Suma, Muhammad Amin. Hukum Keluarga Islam di Dunia Islam (Jakarta: Raja Grafindo, 2004)

Sollchah, Romadhoni Hanifah, Prihatina Lisa dan Putri Novyana Optimalisasi Peran KUA dalam Mengatasi IlegalWedding, Jurnal Privat Law III, No. 2 (JuliDesember, 2015)

Sugiyono, Metode Penelitian Pendidikan pendekatan kuantitatif, Kualitatif dan $R D$, (Cet XVIII; Bandung; Alfabeta, 2013)

Supranto, J. Metode Riset Aplikasinya dalam Pemasaran, (Ed. III; Jakarta: Fakultas Ekonomi UI, 1981)

Suhartono, Irawan. Metode Penelitian Sosial, (Cet. I; Bandung: Remaja Rosdakarya, 2002)

Shihab, Quraish. Wawasan al-Qur'an: Tafsir Maudhu'i Atas Berbagai Persoalan Umat (Cet. VIII; Jakarta: Mizan, 1998)

"Sosiologi" KBBI Daring Online: http://kbbi.kemdikbud.go.id/ent ri/sosiologi (2 Januari 2019)

Tamam, Ahmad Badrut. "Nikah Sirri Solusi Pernikahan Anak di Bawah Umur di Desa Petung, Panceng, Gresik," Al-Ahwal 3, No. 1 (2010)

Turner, Bryan S., Teori Sosial Dari Klasik Sampai Postmodern, (Yogyakarta: Pustaka Pelajar, 2012)

Tanjung, Armaidi. Free Sex No Nikah Yes, Amzah (Jakarta,2017)

Umbara, Tim Citra. Undang-Undang Repuplik Indonesia No 1 Tahun 1974, Tentang Perkawinan dan Kompilasi
Hukum Islam, (Bandung, Citra Umbara, 2001), Cet. 1, 2.

Yayasan Penyelenggara Penerjemah AlQur'an Depertemen Agama RI, Al-Qur'an Tiga Bahasa, (Jakarta: Al-Huda, 2009)

Yasin Nur, Hukum Perkawinan Islam Sarak, Cet.1, (Malang: UIN Malang Press, 2008)

Yudistira, Ainun. "Latar Belakang Filosofis Pencatatan Perkawinan" ElWasathiya 1, No. 2 (2013)

Yusuf ad-Daryuwisy, Ahmad bin. AzZawaj Al-'Urfi, (KSA: Darul Ashimah, Cet I. $1426 \mathrm{H}$ )

al-Zuhaili, Wahbah. Al-Figh Al-Islām Wa Adillatuhu Juz 9, (t.tp: Dar El-Fikr, 1997)

VoA Islam, "RUU Nikah Siri: Ramerame Pidanakan Nikah siri Ulama Menolak". http://www.voaislam.com/read/indonesiana/201 2/12/06/22169/ruu-nikah-siriramerame-mempidanakan-ulama menolak/\#sthash.8AgoDK2m.dpu f. (05 Juni 2019)

Zahri, H. A"Argumentasi Yuridis Pencatatan Perkawinan Dalam Perspektif Hukum Islam".http://badilag.net/data/A RTIKEL/Argumentasi\%20Yuridis $\%$ 20Pencatatan $\%$ 20Perkawinan $\% 2$ 0dlam\%20Perspektif\%20Hukum\% 20Islam.pdf.(01 Juni 2019) 